\title{
Crablet of Mud Crab Scylla Olivacea Production from the Different Stages of Larvae fed Artemia Nauplii Enriched Using Nannochloropsis sp
}

\author{
Gunarto Gunarto (Corresponding Author) \\ Research Institute for Coastal Aquaculture, Maros \\ Jln. Makmur Daeng Sitakka No. 129 Maros-South Sulawesi 90512, Indonesia \\ Tel: +6281342788509 Fax:+62411371545 E-mail : gunartom@yahoo.com
}

\author{
Andi Parenrengi \\ Research Institute for Coastal Aquaculture, Maros \\ Jln. Makmur Daeng Sitakka No. 129 Maros-South Sulawesi 90512, Indonesia \\ Tel+6281315334215 Fax:+62411371545 E-mail : andi parenrengi@hotmail.com \\ Early Septiningsih \\ Research Institute for Coastal Aquaculture, Maros \\ Jln. Makmur Daeng Sitakka No. 129 Maros-South Sulawesi 90512, Indonesia \\ Telp: +6281355951270 Fax: +62411371545 E-mail : earlyseptiningsih@gmail.com
}

(Received: Nov 5, 2016; Reviewed: Nov 10, 2016; Accepted: Nov 26, 2016)

\begin{abstract}
Improvement of feed quality for mangrove crab larvae rearing is one of the important factors to increase of crablet production. The aim of the research was to know the influenzing of enriched Artemia nauplii using Nannochloropsis sp fed to the different stages of larvae Scylla olivacea on crablet production. Twelve units of tanks volume 250 L filled with saline water salinity $30 \mathrm{ppt}$, aerated, then stocked with new hatched mud crab larvae zoea-1 at the density 100 ind./L. The larvae zoea-1 were fed rotifer, Brachionus sp. and after zoea-3, beside fed by rotifer, the larvae were also fed by Artemia naupli. Four treatments were tested, namely: A). Artemia nauplii enriched using Nannochloropsis sp. was given to the larvae zoea-3 until develop to megalop stage. B). Artemia nauplii enriched using Nannochloropsis sp was given to the larvae zoea-4 until develop to megalop stage. C). Artemia nauplii enriched using Nannochloropsis sp was given to the larvae zoea-5 stage until develop to megalop stage. D). Artemia nauplii without enriched using Nannochloropsis sp. was given to the larvae zoea-3 until develop to megalop stage. Result of the research showed that the highest of Larvae Development Indexes and Megalop Occurence Indexes was obtained in treatment $\mathrm{A}$ and resulted the highest of crablet production, then followed by treatment $\mathrm{C}$ and $\mathrm{B}$ and those were significantly different $(\mathrm{P}<0.05)$ with the crablet production in treatment D. The use of Artemia nauplii enriched by Nannochloropsis sp. to feed larvae, S. olivacea stage zoea-3 to zoea-5 until develop to the megalop stage is one of the key factor to enhance the crablet production. By this finding, the crablet production in hatchery will be increased and the mud crab culture in brackishwater pond able to developed.
\end{abstract}

Keywords: Scylla olivacea;crablet; Nannochloropsis sp: Artemia; enriched 


\section{Introduction}

Mud crab commonly also called mangrove crab is an important source of income for small scale coastal rural people in some part area of Indonesia. There are recognized any four species of mangrove crab namely; Scylla serrata, S. transquebarica, S. olivacea and S. paramamosain (Keenan et al., 1998). S. olivacea is dominant species of mangrove crab in South Sulawesi waters, Indonesia (Herlinah and Septiningsih, 2015). Due to high economic value of the mud crab, it has been impacted to the high suppresing of that mangrove crab in the wild and the previous study was indicated an overexploitation of mangrove crab, S. olivacea in the mouth river of Cenranae, Bone Regency, South Sulawesi, Indonesia (Gunarto et al., 1999). To minimize an overexploitation, the mangrove crab culture in the brackishwater pond where the seed from hatchery could be developed. Earlier research on mangrove crab seed production was reported in some countries such as Taiwan (Chen and Cheng, 1985); Phillipphina (Quinitio et al, 2001); Japan (Hamasaki et al, 2002), Malaysia (Anuar et al, 2011) and Indonesia (Yunus et al, 1997). However, crablet production in hatchery is still low. Karim (2006) and Suprayudi et al. (2012) reported that the lower of mangrove crab production was caused by the low of feed quality. An improving of feed quality is very important and crucial to be conducted to enhancing mangrove crab larvae viability. Bioencapsulated of rotifer as well as Artemia nauplii using fatty acid such High Unsaturated Fatty Acid (HUFA) was recomended before they were fed to the mangrove crab larvae. It was due to EPA (Eicosa Pentaeno- ic Acid) and DHA (Docosa Hexaenoic Acid) content in rotifer, Brachionus plicatilis and Artemia nauplii relatively low (Yousefian and Najafpour, 2011; Adloo et al., 2012).

To improve EPA and DHA content in rotifer and Artemia naupli, beside enriched using HUFA, they can be also enriched using algae, such Chlorella spp (Truong et al., 2007b). Shigeki and Hamasaki (2012) reported that rotifer enriched using HUFA and fed to the $S$. serrata larvae is able to more enhanced larvae development. However, mortality syndrome often occured in molted larvae (Hamasali et al., 2002a). Ferreira et al. (2009) stated that rotifer fed sufficient of Nannochloropsis gaditana would twofold increase of protein, lipid and carbohydrate content. The DHA/EPA ratio also increase from 0.063 in rotifer without enriched with Nannochloropsis sp to 0.147 in rotifer enriched with Nannochloropsis sp (Gunarto and Herlinah, 2013). Whereas Gunarto and Herlinah (2015) reported that rotifer was enriched using HUFA the DHA/EPA ratio was increased $69.23 \%$, while Artemia nauplii enriched with HUFA the DHA/EPA ratio was increased only $28.72 \%$. Enhancing of DHA/ EPA ratio in rotifer and artemia is very important to increasing the succeed of larvae zoea stage develop to the next stage (Truong et al., 2007a).

Nannochloropsis sp is one of the best phytoplankton as a feed for rotifer, Brachionus sp. Jean and Hur (2011), stated that the content of fatty acid 22: 6n-3, DHA and 20 5n-3, EPA in Nannochloropsis sp was 0,29\% and $34,88 \%$, respectively. Nannochloropsis $\mathrm{sp}$ concentrated or alive was used to enriched rotifer and Artemia nauplii (Mat- 
thew et al., 2006) and fed to fish/crustacean larvae would improve larvae vitality, it was because of EPA dan DHA content in rotifer as well as in Artemia nauplii were increased (Okauchi, 2004).

The mangrove crab stages consist of five level of zoea stage, namely zoea-1, zoea2 , zoea-3, zoea-4 and zoea-5, then megalop stage and lasted is crablet stage. In what level of zoea stage the most effective to the larvae were started be given fed Artemia nauplii enriched by Nannochloropsis sp in order to enhancing crablet production. The aim of the research was to find out the effect of enriched Artemia nauplii using Nannochloropsis sp fed to the different stage of larvae S. olivacea on crablet production.

\section{Materials and Method}

Research was conducted during January to February 2016 in wet laboratory at Station of Research Institute for Coastal Aquaculture at Marana, Maros - Indonesia. Twelve units of conical fiberglass tanks volume $250 \mathrm{~L}$ was filled with $200 \mathrm{~L}$ of sterile sea water salinity 30 ppt with aeration system. The healthy new hatched of mangrove crab larvae were stocked in those tanks at the density of 100 ind./L. Water temperature and dissolved oxygen in the tanks was $29-30^{\circ} \mathrm{C}$ and 7-8.5 $\mathrm{mg} / \mathrm{L}$ respectively.

Rotifer were given to the larvae zoea-1 to zoea-3 as feed at the density of 20 ind./ $\mathrm{mL}$. After larvae develop to the zoea-3, the treatment of feeding using Artemia nauplii enriched with Nannochloropsis sp was started. Before treatment running out, the Artemia cyst were hatched earlier in $50 \mathrm{~L}$ of conical fiber tank filled with $40 \mathrm{~L}$ of sea wa- ter salinity $28 \mathrm{ppt}$ and it was given highly aerated. LED lamp 6 watt was set up near surface water in that tank to accelerate Artemia nauplii hatched. After 24 hours aerated, Artemia nauplii was hatched, then harvested, rinsed with the saline water, and stocked at the density of 500 ind. $/ \mathrm{mL}$ in the basin volume $5 \mathrm{~L}$ filled with $2 \mathrm{~L}$ of sea water salinity $28 \mathrm{ppt}$ and aerated. Two liter of Nannochloropsis $\mathrm{sp}$ from the $5 \mathrm{~L}$ of Nannochloropsis sp culture stock in laboratory was added to Artemia nauplii in the basin to enrichment. The Nannochloropsis sp density was 636 x $10^{4}$ cell $/ \mathrm{mL}$. The enrichment was conducted during 5 hours, then Artemia nauplii was harvested and fed to the different stages of mangrove crab, $S$. olivacea larvae, such it was discribed below as the treatment in this research :

a). Artemia nauplii enriched using Nannochloropsis $\mathrm{sp}$ at the density $636 \times 10^{4}$ cell $/ \mathrm{mL}$ was given to the larvae zoea-3 stage until larvae develop to megalop stage.

b). Artemia nauplii enriched using Nannochloropsis sp at the density $636 \times 10^{4}$ cell/ $\mathrm{mL}$ was given to the larvae zoea-4 stage until larvae develop to megalop stage.

c). Artemia nauplii enriched using Nannochloropsis sp at the density $636 \times 10^{4}$ cell/ $\mathrm{mL}$ was given to the larvae zoea-5 stage until larvae develop to megalop stage.

d). Artemia nauplii unenriched using Nannochloropsis $\mathrm{sp}$, was given to the larvae zoea-3 until larvae develop to megalop stage.

Each treatment was three replications. Artemia nauplii were given to the zoea-3 stage larvae at the density of 3 ind. $/ \mathrm{mL}$ and it 
increased to $5 \mathrm{ind} . / \mathrm{mL}$ at megalop stage. The feeding regime for the larvae was showed in Table 1.

Table 1. Feeding regimes for mangrove crab, S. olivacea larvae

\begin{tabular}{lccc}
\hline Stadium & $\begin{array}{c}\text { Feeding } \\
\text { frequency }\end{array}$ & $\begin{array}{c}\text { Rotifer } \\
\text { density } \\
\text { (ind./mL) }\end{array}$ & $\begin{array}{c}\text { Artemia nauplii } \\
\text { density (ind/mL) }\end{array}$ \\
\hline Zoea-1 & 1 & 20 & - \\
Zoea-2 & 1 & 20 & - \\
Zoea-3 & 1 & 20 & 3,0 \\
Zoea-4 & 1 & 10 & 4,0 \\
Zoea-5 & 1 & 10 & 4,0 \\
Megalopa & 1 & - & 5,0 \\
\hline
\end{tabular}

Addition of sea water in the larvae rearing tanks was conducted after 5 days larvae rearing at about $10 \%$ of total water volume and exchanged water conducted after 8 days of culture at the $10 \%$ of total water volume. However, after zoea-5, the exchanged water increase to about $50 \%$ of total water volume and conducted at every two days. Larvae population from zoea-1 to zoea-5 were monitored using chamber volume 50 $\mathrm{mL}$ for zoea-1 to zoea-3 and volume 250 $\mathrm{mL}$ for zoea- 4 and zoea- 5 by inserted that chamber to the different places of surface water in the tank. The larvae included in the water were counted manually. Larvae density were calculated in ind./L. Whereas, larva development were monitored by sampled of 20 ind. of larvae in each replication of each treatment, then the status of larvae stage was also identified.

\subsection{Larvae Development Index}

The Larvae Development Index (LDI) is the value which described the expression of the fast of larvae development in the culture rearing tank. The LDI was calculated by the score to the each stage of larvae such zoea- $1=1$, zoea- $2=2$, zoea- $3=3 \ldots$ to meg- alop $=6$ (Truong et al., 2007b). In example of 20 ind. consisted of 5 ind. was zoea-3, 8 ind. was zoea-4 and 7 ind. was zoea-5, that mean the $\mathrm{LDI}=(5 \times 3+8 \times 4+7 \times 5) / 20=4,1$

\subsection{Megalop Occurence Indexes}

At the day of culture (DOC) 20 larvae started metamorphosis to the megalop stage. Megalops population were monitored by calculated Megalop Occurence Index (MOI). MOI is the value which described the expression a numbers of megalops stage available in the culture tank. MOI was determined by calculated the occurence of megalops at determined numbers of larvae zoea-5 stage. In example from 100 individuals of larvae were counted only 5 individuals of megalops included, then the MOI value was 0.05 . The MOI value would increase during 2-4 days, when the zoea-5 gradually metamorphosis to the megalop stage, then the MOI value decreased after megalop lay down in the bottom of the tank to metamorphose to the crablet instar 1 .

\subsection{Water Quality and Total Vibrio sp Monitoring}

Sampled of $300 \mathrm{~mL}$ of water was taken from the conical fiber tank of each replication in each treatment at the day 10 and 20 then brought to the laboratory to analyze water quality parameters such as ammonium, nitrite and Total Organic Matter (TOM) and $50 \mathrm{~mL}$ of water sample was also taken using dark, sterile bottle sample in each treatment to analyze of total Vibrio sp. To know the effect of the treatment to the larvae population, megalop survival and crablet production, the data obtained were compared and tested 
usinqg Complete Randomized Design Analysis, and following by LSD test to know which treatment was significant different each others. The SPSS (Statistical Product Service Solution) program was used to help an analysis for those data.

\section{Results and Discussion}

\subsection{Larvae Development}

The fast of mangrove crab larvae development was determined by the health of larvae, feed quality, quantity and suitability of environmental parametric for larvae life and development. The DHA and EPA content in the feed influenced to the larvae development and survival rate at the late stage (Ribeiro and Jones, 2000: Hamasaki et al., 2002; Davis, 2004). Truong et al. (2007a) reported that the high ratio of DHA/EPA in rotifer and Artemia nauplii is better to accelerate the development of $S$. paramamosain larvae. The different stage of larvae was determined by total number of plumose setae and pleopod performance in the larvae (Figure 1).

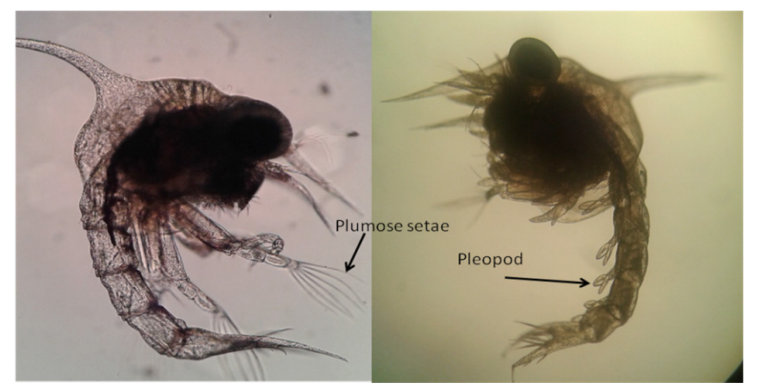

A B

Figure 1. Larvae zoea-2 with 6 plumose setaes (A) and larvae zoea-5 with long of pleopod (B)

The present study showed that development of larvae from zoea-1 with 4 plumose setaes to the zoea- 2 stage with six of plumose setae was required 6 days. The zoea-2 stage to zoea-3 stage was required 4 days. At the zoea-3 stage with 8 plumose setaes develop to zoea- 4 was required 3 days. Zoea-4 stage was indicated with bud of pleopod showing in the abdomen and developed to zoea-5 was required 4 days. Zoea-5 developed to megalop stage was required 5 days. While megalop develop to the crablet stage need 7 days. The complete $S$. olivacea larvae development to the crablet stage was required about 29 days (Table 2). It seemed to be longer than the S. transquebarica in India that it was reported only required 22 days to completed larvae develop to the crablet stage (Thirunavukkarasu et al., 2014). Hamasaki (2003) reported between 21-42 days for $S$. serrata larvae complete develop to the crab stage when rearing at water temperature 23$32^{\circ} \mathrm{C}$. The different species also different water temperature of rearing, feeding schedule and dosage may responsible to the different time required to complete larvae development to the crablet stage. The larvae of $S$. transquebarica fed Brachionus rotundiformis and Artemia nauplii at libitum twice per day (Thirunavukkarasu et al., 2014), while in this research the $S$. olivacea larvae only fed Brachionus sp at the density of 20 ind. $/ \mathrm{mL}$ and Artemia nauplii at the density 3-4 ind./ $\mathrm{mL}$ and it was given at once per day. This feeding schedule may resulted longer development the larvae in this research. When the larvae zoea-5 fed artemia naupli only at the density $0.5 \mathrm{ind} . / \mathrm{mL}$ resulted more larvae mortality caused by canibalisms (Suprayudi et al., 2002).

In this research the zoea-1 were stocked in the conical fiberglass tank at the density of 400 ind./L. The larvae density of 
zoea-2 stage was dropped to the $360-366$ ind./L. The decreasing of the larvae population continues up to the zoea-3 stage, where their population was $343.0 \pm 15.6$ ind./L (A), $320.3 \pm 17.6$ ind./L (B), 334.01 \pm 1.7 ind./L (C) and $321.03 \pm 7.15$ ind./L (D). The zoea-4 stage started obtained at the day 11, where at the day 14 the larvae population was dropped to $161.7 \pm 38.9$ ind./L (A), $144.0 \pm 34.2 \mathrm{ind} / \mathrm{L}$

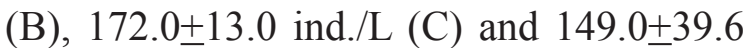
ind./L (D). The dropped sharply in zoea-3 to the zoea- 4 stage may caused by limiting of Artemia naupli supplied to the larvae in the tank. In this research the artemia naupli was given to the zoea-3 at the density of 3-4 ind./mL. Truong et al. (2007b) reported that after larvae develop to zoea-3 until zoea-5 stage the feed should adjusted depending on

Table 2. Identification of larvae development and period required by each stage

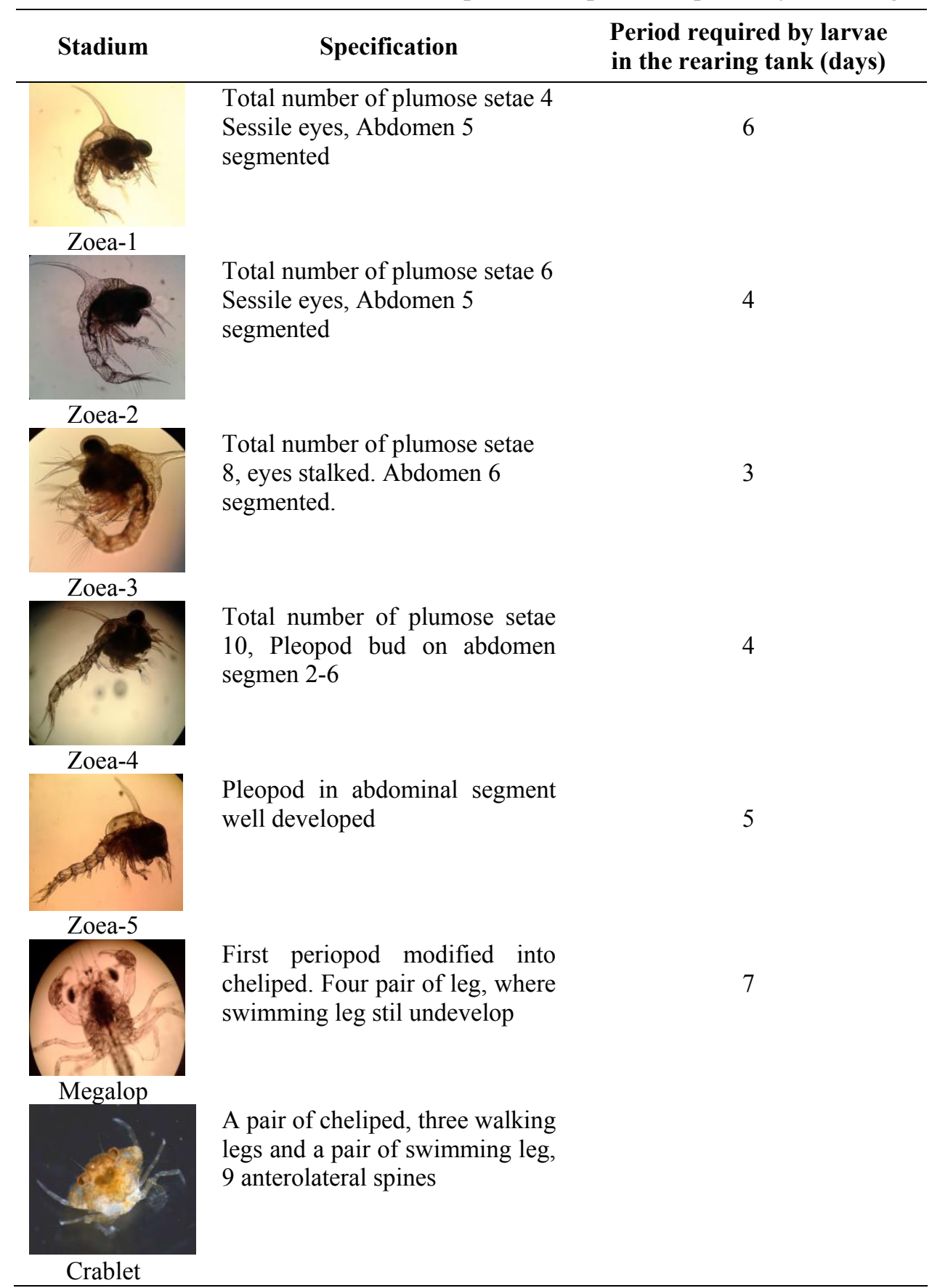


Table 3. Population of mangrove crab S. olivacea larvae fed Artemia nauplii enriched and unenriched using Nannochloropsis sp

\begin{tabular}{cccccc}
\hline & \multicolumn{5}{c}{ Larvae population (ind./L) from zoea-1 to zoea-5 stage } \\
\cline { 2 - 6 } Treatments & Day- 1 & Day-7 & Day-11 & Day-14 & Day-21 \\
\cline { 2 - 6 } & Z-1 (ind/L) & Z-2 (ind/L) & Z-3 (ind/L) & Z-4 (ind/L) & $\begin{array}{c}\text { Z-5 and megalopa } \\
\text { (ind/L) }\end{array}$ \\
\hline A. & 400 & $377.3 \pm 19.6^{\mathrm{a}}$ & $343.0 \pm 15.6^{\mathrm{a}}$ & $161.7 \pm 38.9^{\mathrm{a}}$ & $54.3 \pm 6.0^{\mathrm{a}}$ \\
B. & 400 & $355.81 \pm 19.0^{\mathrm{a}}$ & $320.3 \pm 17.6^{\mathrm{a}}$ & $144.0 \pm 34.2^{\mathrm{a}}$ & $44.0 \pm 6.92^{\mathrm{a}}$ \\
C. & 400 & $388.73 \pm 6.2^{\mathrm{a}}$ & $334.01 \pm 1.7^{\mathrm{a}}$ & $172.0 \pm 13.1^{\mathrm{a}}$ & $57.3 \pm 2.30^{\mathrm{a}}$ \\
D. & 400 & $362.3 \pm 12.7^{\mathrm{a}}$ & $321.03 \pm 7.15^{\mathrm{a}}$ & $149.0 \pm 39.6^{\mathrm{a}}$ & $45.7 \pm 12.4^{\mathrm{a}}$ \\
\hline
\end{tabular}

Notes : A). Artemia nauplii enriched using Nannochloropsis sp was given to the larvae zoea-3 stage until develop to megalop stage. B). Artemia nauplii enriched using Nannochloropsis sp was given to the larvae zoea-4 stage until develop to megalop stage. C). Artemia nauplii enriched using Nannochloropsis sp was given to the larvae zoea-5 stage until develop to megalop stage. D). Artemia nauplii without enriched using Nannochloropsis sp was given to the larvae zoea-3 until develop to megalop stage.

the species, larvae stage, larvae status, prey size, rearing system and techniques, the rotifer should be increase from zoea-1 to zoea2 at the density 40 ind./mL, while Artemia nauplii should be increased to $10-15$ ind./ $\mathrm{ml}$ after larvae reach stage zoea-3 to zoea-4.

In this research the zoea-5 stage was detected at the day 15. At this time, the larvae population was dropped to $54.3 \pm 6.0$ ind./L

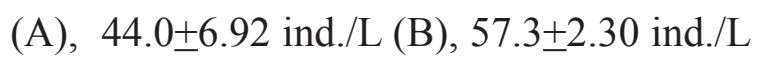
(C) and $45.7 \pm 12.4$ ind/L (D). That mean only about $11-13 \%$ of larvae zoea-1 develop to the zoea-5 stage. Epibiotic bacteria and larval mycosis most affected mortality to the mud crab larvae from zoea-1 to the zoea-5 (Truong et al., 2007b). The megalop stage was detected at the day 21 of rearing and occurence of megalop in each treatment was performed in the Megalop Occurences Indices (MOI). The statistical analysis to the zoea population (zoea-1 to zoea-5 stage) among that treatments were not significant different $(\mathrm{P}>0.05)$ (Table 3).

\subsection{Larvae Development Index}

Larvae Development Indexes (LDI) is the value which indicates to the larvae development. At the day 18 of culture it was observed that $50 \%$ of larvae in treatment $\mathrm{A}$ has developed to the zoea-5 stage, it was also obtained in larvae of treatment $\mathrm{C}$ and $\mathrm{D}$, while larvae in treatment $B$ seemed to be late develop. At the day 21, most of the larvae has developed to the zoea-5 in treatment $\mathrm{A}$ and $\mathrm{C}$. There are a few numbers of zoea5 succeed metamorphosis to the megalop stage. This situation was also observed in treatment $\mathrm{C}$. The zoea-4 develop to zoea-5 stage attained to $86 \%$ and $92 \%$ of the larvae population in treatment $\mathrm{B}$ and $\mathrm{D}$, meanwhile the megalop stage was still unobserved in treatment $\mathrm{B}$ and $\mathrm{D}$. That means the larvae in treatment $\mathrm{B}$ and $\mathrm{D}$ were late to develop to the next stage compared than those of larvae in treatment $\mathrm{A}$ and $\mathrm{C}$. It was due to the larvae in treatment D only fed Artemia nauplii with lower of DHA and EPA, not any addition 
of DHA and EPA from Nannochloropsis sp enriched to the Artemia nauplii, thus resulted late of larvae development and low of larvae vitality (Matthew et al., 2006). Futhermore Hamasaki et al. (2002) also reported that the mud crab $S$. serrata larvae morphogenesis was accelerated according to the HUFA content in their natural feed.

In the 24 days of culture showed that $25 \%$ of larvae zoea- 5 stage in treatment $A$ had developed to the megalop stage. That mean the larvae in treatment A continuous develop to megalop stage in the next day. Larvae in treatment B were also continuously developing from zoea stage to megalop stage. It can be seen from the LDI value at 4.86 on the day 21 , then develop to 5.18 on the day 24. While in treatment $\mathrm{C}$ the LDI value was seen decreased namely from 5,09 on the day 21 to 4,92 on the day 24 . The decreasing LDI value also was observed in treatment $\mathrm{D}$ from 4.92 on the day 21 decreased to 4.67 on the day 24 (Table 4 ). That means in treatment $\mathrm{C}$ and $\mathrm{D}$ the larvae development was unaccelerated, even thought in the treatment C, Artemia nauplii was enriched using Nannochloropsis sp, but it was given to the larvae zoea-5. While in treatment D the $\mathrm{Ar}$ temia nauplii fed to the larvae zoea-3 stage but was not enriched using Nannochloropsis sp. Besides that larvae also given commercial of artificial feed at the dosage of 1 $\mathrm{mg} / \mathrm{L}$. Meanwhile, this treatment did not impact to the accelerating larvae development. That phenomenon seemed to be concluded that Artemia nauplii which enriched using Nannochloropsis sp would increase DHA/ EPA and then fed to the larvae zoea-3 stage was more effective to accelerated the larvae development to the megalop stage. The contrary, the larvae zoea-5 stage fed Artemia nauplii enriched Nannochloropsis sp (treatment C) or larvae zoea-3 fed Artemia nauplii unenriched using Nannochloropsis sp but added artificial feed (treatment D) seemed to be less developed to the next stages (Table 4). Anuar et al. (2011) reported that larvae $S$. serrata fed unenrich Artemia nauplii showed

Table 4. Larvae Development Indexes of mangrove crab S. olivacea larvae fed Artemia nauplii enriched and unenriched using Nannochloropsis sp

\begin{tabular}{ccccccccc}
\hline DOC (day) & $\mathbf{1}$ & $\mathbf{7}$ & $\mathbf{9}$ & $\mathbf{1 1}$ & $\mathbf{1 4}$ & $\mathbf{1 8}$ & $\mathbf{2 1}$ & $\mathbf{2 4}$ \\
\hline Larvae Stage & $\mathrm{Z}-1$ & $\mathrm{Z}-2$ & $\mathrm{Z}-3$ & $\mathrm{Z}-3$ & $\mathrm{Z}-4$ & $\mathrm{Z}-5$ & $\begin{array}{c}\mathrm{Z}-5 \text { and } \\
\text { Megalop }\end{array}$ & $\begin{array}{c}\mathrm{Z}-5 \text { and } \\
\text { Megalop }\end{array}$ \\
\hline Treatment & 1 & $1.7 \pm 0.07^{\mathrm{a}}$ & $2.1 \pm 0.1^{\mathrm{a}}$ & $2.6 \pm 0.03^{\mathrm{a}}$ & $3.2 \pm 0.03^{\mathrm{a}}$ & $4.5 \pm 0.05^{\mathrm{a}}$ & $5.09 \pm 0.47^{\mathrm{a}}$ & $5.25 \pm 0.2^{\mathrm{a}}$ \\
\hline A & 1 & $1.7 \pm 0.07^{\mathrm{a}}$ & $2.2 \pm 0.2^{\mathrm{a}}$ & $2.6 \pm 0.1^{\mathrm{a}}$ & $3.3 \pm 0.03^{\mathrm{a}}$ & $4.3 \pm 0.06^{\mathrm{a}}$ & $4.86 \pm 0.03^{\mathrm{a}}$ & $5.18 \pm 0.5^{\mathrm{a}}$ \\
B & 1 & $1.7 \pm 0.1^{\mathrm{a}}$ & $2.1 \pm 0.1^{\mathrm{a}}$ & $2.6 \pm 0.03^{\mathrm{a}}$ & $3.3 \pm 0.03^{\mathrm{a}}$ & $4.5 \pm 0.03^{\mathrm{a}}$ & $5.09 \pm 0.01^{\mathrm{a}}$ & $4.92 \pm 0.1^{\mathrm{b}}$ \\
C & 1 & $1.5 \pm 0.07^{\mathrm{a}}$ & $2.1 \pm 0.1^{\mathrm{a}}$ & $2.5 \pm 0.1^{\mathrm{a}}$ & $3.2 \pm 0.03^{\mathrm{a}}$ & $4.5 \pm 0.20^{\mathrm{a}}$ & $4.92 \pm 0.04^{\mathrm{a}}$ & $4.67 \pm 0.4^{\mathrm{b}}$ \\
\hline
\end{tabular}

Notes: A). Artemia nauplii enriched using Nannochloropsis sp was given to the larvae zoea-3 stage until develop to megalop stage. B). Artemia nauplii enriched using Nannochloropsis sp was given to the larvae zoea-4 stage until develop to megalop stage. C). Artemia nauplii enriched using Nannochloropsis sp was given to the larvae zoea-5 stage until develop to megalop stage. D. Artemia nauplii without enriched using Nannochloropsis sp was given to the larvae zoea-3 until develop to megalop stage. 
clear sign of essensial fatty acid defisiency, prolong intermolt period, low survival and reduce swimming activity.

DHA and EPA has been known to be important thing in the development of mud crab larvae. The DHA and EPA content in Artemia nauplii was low. Enriched Artemia nauplii using Nannochloropsis sp wil be increased the content of EPA, DHA and omega fatty acid in Artemia nauplii (Hamasaki et al., 2002; Okauchi, 2004; Truong et al., 2007a; Jean and Hur, 2011; Suprayudi et al., 2012; Gunarto and Herlinah, 2013). That mean the feed quality for larvae will increases after enriched using Nannochloropsis sp (Churchil, 2003). Besides an enhancing of DHA/EPA rasio in rotifer, Brachionus sp and Artemia nauplii enriched with Nannochloropsis gaditana, it would also increasing of protein, lipid and carbohydrate content (Ferreira et al., 2009). Larvae will increase vitality and viability after fed artemia naupli enriched using HUFA (Karim, 2006). The ratio of DHA and EPA in life feed is the key factor responsible to the success of mangrove crab larvae develop to the next stages (Truong et al., 2007a; Sui et al., 2007).

The DHA/EPA ratio in rotifer and artemia nauplii after enriched using HUFA and Nannochloropsis sp. in this research showed in Table 5. The DHA/EPA ratio in rotifer after enriched using HUFA at $20 \mathrm{mg} / \mathrm{L}$ during 1 hour was 1.210. Gunarto and Herlinah, (2015) obtained that the DHA/EPA ratio in rotifer without enriched using HUFA was 0.063 That mean the DHA/EPA ratio was increased to $1820 \%$. Artemia nauplii after enriched using HUFA at $50 \mathrm{mg} / \mathrm{L}$ during 5 hours, the DHA/EPA ratio in this research was 0.221 and there was increased to 0.294 after artemia nauplii also enriched using Nannochloropsis sp at the density of 636 $\mathrm{x} 10^{4} \mathrm{cell} / \mathrm{mL}$. That mean the DHA/EPA ratio was increased to $33.032 \%$. Earlier research the DHA/EPA ratio in rotifer after enriched using HUFA at $20 \mathrm{mg} / \mathrm{L}$ during three hours was only increased to $69.23 \%$, while in artemia nauplii after enriched using HUFA at $300 \mathrm{mg} / \mathrm{L}$ during five hours was increased to 28.72\% (Gunarto and Herlinah, 2015).

Table 5. The DHA/EPA ratio in rotifer and artemia nauplii after enriched using HUFA and Nannochloropsis sp.

\begin{tabular}{lccc}
\hline \multirow{2}{*}{ Sample } & EPA & DHA & DHA/EPA \\
\cline { 2 - 4 } & $(\mathrm{mg} / 100 \mathrm{~g})$ & $(\mathrm{mg} / 100 \mathrm{~g})$ & Ratio \\
\hline Rotifer + HUFA & 50.2 & 61 & 1.21 \\
Nauplius Artemia + HUFA & 37.5 & 8.3 & 0.221 \\
$\begin{array}{l}\text { Nauplius Artemia + HUFA } \\
\text { +Nannochloropsis sp }\end{array}$ & 44.1 & 13,0 & 0.294 \\
\hline
\end{tabular}

\subsection{Megalop Occurence Indexes and Crab- let Production}

The value of Megalop Occurence Indexes (MOI) at the first day (DOC 21) was very low due to only a few of zoea-5 succced metamorphosis to the megalop stage. At the second days (DOC 22) the highest MOI was observed in C (0.14), followed D treatment (0.11), In earlier study Gunarto et al. (2016) was obtained MOI value of $S$. serrata at the second day was 0.13 , where the larvae started from the zoea-3 stage also was fed with artemia naupli enriched using Nannochloropsis $\mathrm{sp}$ at the density of $636 \times 10^{4} \mathrm{sel} / \mathrm{mL}$. At the third day (DOC 23) the highest of MOI value was obtained in A treatment (0.242), then followed by $\mathrm{C}$ treatment (0.208), whereas B and $\mathrm{D}$ treatment the MOI value relative stagnant namely 0.034 and 0.123 . At the fourth day (DOC 24) the highest of MOI value still 
in A treatment (0.294), then followed by C (0.242), D (0.105) and B treatment (0.118). it can be concluded that the peak of MOI value obtained at the fourth day in all treatments (Table 6). After five days, the megalop become benthic and stayed in the bottom of the tank to start metamorphosis to the crablet stage. At the sevent days after occurences of megalop, the crablet instar-1 was observed in the bottom of the tank. From the MOI value development in all treatments, it was indicated that larvae in A treatment was more simultant develop to the megalop stage, even was only $29 \%$ of larvae population after 4 days from megalop appearance in the culture rearing of mud crab larvae. Then followed by larvae in the C (24\%), B treatments $(22 \%)$ and the smalest simultant was obtained in D treatment $(10 \%)$, This situation was proved that enriched Artemia nauplii using Nannochloropsis sp was affected to the more synchronizing of zoea-5 metamorphosis to the megalop stage.

The highest of D-10 crablet production with various size namely, 0.003-0.02 g/ ind. was obtained in A treatment $(191 \pm 15.6$ ind./tank), then followed by $\mathrm{C}$ treatment (190.5 \pm 13.4 ind./tank), B treatment (165.5 $\pm 7.1 \mathrm{ind} . / \operatorname{tank})$ and those were significant different $(\mathrm{P}<0.05)$ with the lowest of crablet production was obtained in D treatment (121.5 \pm 2.1 ind./ tank). The various size of crablet production was represented that larvae developement stage in the same tank was different. Thereafter, even in the tank was find out the crablet, but the megalops were still observed swimming or megalop as a benthic in the bottom of the tank to initiate metamorphosis to the crablet stage. The bigger size of crablet that mean the larvae fast develop to crablet stage. It was due to unsyncronizing of larvae development, there mean the canibalisms oportunity become the bigger mostly by megalop to the zoea- 5 stage or by the crablet to megalops stayed in the tank bottom. Thus the unsynchronizing of zoea-5 metamorphosis to the megalop stage would result the lower crablet production.

The next reseach could be focused to the aspect of how to minimize of unsyncronizing larvae development in the rearing tank. The optimum number of larvae stock-

Table 6. The Megalop Occurence Indexes (MOI) of mangrove crab S. olivacea larvae fed Artemia nauplii enriched and unenriched using Nannochloropsis sp

\begin{tabular}{|c|c|c|c|c|c|}
\hline \multirow{2}{*}{ Treatments } & \multicolumn{5}{|c|}{$\begin{array}{c}\text { Megalop Occurence Indexes ( ind. of megalop/100 ind. of larvae) } \\
\text { and crablet production in each treatment }\end{array}$} \\
\hline & $\begin{array}{l}\text { First day } \\
(\mathrm{DOC} 21)\end{array}$ & $\begin{array}{l}\text { Second day } \\
\text { (DOC 22) }\end{array}$ & $\begin{array}{l}\text { Third day } \\
\text { (DOC 23) }\end{array}$ & $\begin{array}{l}\text { Fourth day } \\
\text { (DOC 24) }\end{array}$ & $\begin{array}{l}\text { Crablet-D10 } \\
\text { (ind./tank ) }\end{array}$ \\
\hline A & $0.03^{\mathrm{a}}$ & $0.053^{\mathrm{a}}$ & $0.242^{\mathrm{a}}$ & $0.294^{\mathrm{a}}$ & $191 \pm 15.6^{\mathrm{a}}$ \\
\hline B & $0.01^{\mathrm{a}}$ & $0.034^{\mathrm{a}}$ & $0.034^{\mathrm{b}}$ & $0.218^{\mathrm{a}}$ & $165.5 \pm 7.1^{\mathrm{a}}$ \\
\hline C. & $0.008^{\mathrm{a}}$ & $0.140^{\mathrm{b}}$ & $0.208^{\mathrm{a}}$ & $0.242^{\mathrm{a}}$ & $190.5+13.4^{\mathrm{a}}$ \\
\hline D. & $0.02^{\mathrm{a}}$ & $0.115^{b}$ & $0.123^{\mathrm{b}}$ & $0.105^{\mathrm{b}}$ & $121 \pm 2.1^{b}$ \\
\hline
\end{tabular}

Notes : A). Artemia nauplii enriched using Nannochloropsis sp was given to the larvae zoea-3 stage until develop to megalop stage. B). Artemia nauplii enriched using Nannochloropsis sp was given to the larvae zoea-4 stage until develop to megalop stage. C). Artemia nauplii enriched using Nannochloropsis sp was given to the larvae zoea-5 stage until develop to megalop stage. D). Artemia nauplii without enriched using Nannochloropsis sp was given to the larvae zoea-3 until develop to megalop stage. 
ing density and the feeding regimes presumably to be important factors influenced to the syncronizing of larvae development. By syncronizing larvae development in the rearing tank that mean the larvae almost in the same stage development, therefore, the canibalism in megalop and crablet stage able to minimizing and finally, will be resulted the higher number of crablet production.

\subsection{Water Quality and Vibrio sp Population}

The range value of water quality parameters in mud crab larvae rearing during this study was presented in Table 7. Larvae reared at the water temperature $27-29^{\circ} \mathrm{C}$, salinity 28 ppt, dissolved oxygen (6.5$7.2 \mathrm{mg} / \mathrm{L})$. Gunarto and Widodo (2012) find out higher survival rate of $S$. olivacea larvae reared at the water temperature $30-31,5^{\circ} \mathrm{C}$ compared than that larvae reared at the water temperature $28-29.5^{\circ} \mathrm{C}$. Baylon (2011) claimed that $S$. olivacea larvae development was delayed for 5-10 days on zoea-3 stage after reared at salinity 25-35 ppt and water temperature $20^{\circ} \mathrm{C}$. Ammonium concentration in the larvae rearing tank was relatively $\operatorname{high}(\mathrm{A}=0.11 \mathrm{mg} / \mathrm{L} ; \mathrm{B}=0.08 \mathrm{mg} / \mathrm{L}, \mathrm{C}=0,12$ $\mathrm{mg} / \mathrm{L} ; \mathrm{D}: 0.20 \mathrm{mg} / \mathrm{L}$ ) at the day 6 of culture. The water excanged in larvae rearing was only $10 \%$ of total water volume started at the day 6 of culture At the day 20, when larvae started metamorphosis to the megalop stage, the highest of ammonium concentration was observed in D treatment $(0.24 \mathrm{mg} / \mathrm{L})$. While the other treatment the ammonium concentration was relatively in lower concentration, namely A $(0.13 \mathrm{mg} / \mathrm{L}), \mathrm{B}(0.14 \mathrm{mg} / \mathrm{L})$ and $C(0.13 \mathrm{mg} / \mathrm{L})$ (Table 6$)$. That mean addition of artificial feed in $\mathrm{D}$ treatment could be responsible to increase the ammonium concentration. Nell et al. (2005) found LC50 during 24 hours of $S$. serrata stadia larvae zoea-1 and zoea-5 to the amonia unionized were $4,05 \mathrm{mg} / \mathrm{L}$ and $6,45 \mathrm{mg} / \mathrm{L}$. respectively. Based to that data can be concluded that mortality of the larvae during this research was not caused by ammonium concentration in the tank. It is because of the ammonium concentration still far from the LC-50 value. The lowest of nitrite concentration was detected at the day 6 of culture, but at the 20 day of culture, the nitrite concentration was relatively high at B $(2.24 \mathrm{mg} / \mathrm{L})$ and $\mathrm{D}$ treatment $(1.21 \mathrm{mg} / \mathrm{L})$ and the lowest concentration found at $\mathrm{A}$ treatment $(0.47 \mathrm{mg} / \mathrm{L})$. The LC-50 during 96 hours on zoea-1, 2, 3, 4, 5 of $S$. serrata larvae namely ; 41,58; 63,04; 25,54; 29,98; and 69,93 $\mathrm{mg} / \mathrm{L}$ respectively (Mary et al., 2007).

The Total Organic matter (TOM) concentration was relatively high in all treatments $(>50 \mathrm{mg} / \mathrm{L})$ and the peak obtained in $\mathrm{D}$ treatment $(56 \mathrm{mg} / \mathrm{L})$ and that it was resulted high population of total Vibrio sp in all treatments namely $10^{3} \mathrm{cfu} / \mathrm{mL}$ at the 6 days of culture, while at the day 20 of culture, the Vibrio sp population decreased to $10^{2} \mathrm{cfu} / \mathrm{mL}$, except in D treatment the Vibrio sp population was still at the level of $10^{3}$ cfu./mL. This situation was proved that the addition of artificial feed would influence to the increase of Vibrio sp population in larvae rearing in tank. Zhenguo et al. (2010) claimed that some factors most influenzing to the crablet production consist of micro environment, water quality, rearing. Technique, total Vibrio sp and feed quality and quantity were given to the larvae. 
Table 7. The range value of water quality parameters in mud crab larvae rearing

\begin{tabular}{cccccc}
\hline Treatments & $\begin{array}{c}\text { Amonium } \\
(\mathbf{m g} / \mathbf{L})\end{array}$ & $\begin{array}{c}\text { Nitrite } \\
(\mathbf{m g} / \mathbf{L})\end{array}$ & $\begin{array}{c}\text { TOM } \\
\mathbf{m g} / \mathbf{L}\end{array}$ & Vibrio $\boldsymbol{s} \boldsymbol{p}$ & Vibrio $\boldsymbol{s} \boldsymbol{p}$ \\
\hline & & & & (log $c f u / m L)$ & (log $c f u / m L)$ \\
\hline & & & & At zoea-2 stage & At megalop stage \\
\hline A & $0.11-0.13$ & $0.41-0.47$ & $53,2-56,9$ & $3.81+0.19$ & $2.71+0.03$ \\
B & $0.08-0.14$ & $0.63-2.24$ & $51,5-52,5$ & $3.77+0.05$ & $2.82+0.01$ \\
C & $0.12-0.13$ & $0.51-0.58$ & $50,1-52,5$ & $3.59+0.01$ & $2.91+0.11$ \\
D & $0.20-0.24$ & $0.15-1,21$ & $56,3-56,9$ & $3.78+0.22$ & $3.77+0.23$ \\
\hline
\end{tabular}

Notes : A). Artemia nauplii enriched using Nannochloropsis sp was given to the larvae zoea-3 stage until develop to megalop stage. B). Artemia nauplii enriched using Nannochloropsis sp was given to the larvae zoea-4 stage until develop to megalop stage. C). Artemia nauplii enriched using Nannochloropsis sp was given to the larvae zoea-5 stage until develop to megalop stage. D). Artemia nauplii without enriched using Nannochloropsis sp was given to the larvae zoea-3 until develop to megalop stage.

\section{Conclusion}

Larvae zoea-3 to megalop stage fed unenriched Artemia nauplii, showed the lower of crablet production compared than that of larvae fed Artemia nauplii enriched using Nannochloropsis sp was given to the larvae zoea-3, 4 and 5 untill develop to the megalop stage.

\section{Acknowledgements}

This research was financed by the aquaculture research program DIPA 2016, Research and Development Institute for Coastal Aquaculture, Maros. Ministry of Marine Affair and Fisheries. A team of researchers would like to thank Masyita Makmur, Sainal, Risal, Kamaruddin and Zakaria Spi for their assistance during the research.

\section{References}

Adloo, M. N., Matinfar, A. \& Sourinezhad, I. (2012). Effects of feeding enriched $A r-$ temia franciscana with HUFA, vitamin $\mathrm{C}$ and $\mathrm{E}$ on growth performance, survival and stess resistance of Yellowfin Seabream larvae. Jurnal Aquaculture
Research and Development, 3 (8): 1-5. Anuar, H., Hai, T. N., Anil, C. \& Sukumaran. M. (2011). Preliminary study on the feeding regime of laboratory reared mud crab larva, Scylla serrata (Forsskal, 1775). Word Applied Sciences Journal, 14 (11), : 1651-1654.

Baylon, J. C. (2011). Survival and development of larvae and juveniles of the mud crab Scylla olivacea Forskal (Crustacea: Decapoda: Portunidae) at various temperatures and salinities. Philipp Agric Scientist, 94 (2), : 195-204.

Chen, H. C. \& Cheng. H. (1985). Studies on the larval rearing of serrated crab, Scylla serrata: I. Combined effects of salinity and temperature on the hatching, survival and growth of zoeae, . $J$. Fish. Soc. Taiwan, 12 : 70-77

Churchill, G. J. (2003). An investigation into the captive spawning, egg characteristics and egg quality of the mud crab (Scylla serrata) in South Africa. MSc, Thesis, Rhodes University, Grahamstown, Afrika Selatan. 86 pp.

Davis, J. A. (2004). Development of hatchery techniques for the mud crab Scylla 
serrata (Forskal) in South Africa. Ph.D

Thesis in Applied Biological Sciences. University Gent. Belgia. $156 \mathrm{Hlm}$.

Ferreira, M., Coutinho, P., Seixas, P., Fabregas, J. \& Otero. A. (2009). Enriching rotifers with "premium" microalgae, Nannochloropsis gadinata. Mar Biotechnol (NY) Sept-Oct 11(5) : 585-595. doi : 10.1007/s 10126-008-9174-x.

Gunarto, Rohama, D. \& Usman. (1999). Kecenderungan penurunan populasi kepiting bakau di perairan muara sungai Cenranae, Sulawesi Selatan ditinjau dari analisis parameter sumberdaya. Jurnal Penelitian Perikanan Pantai, 5 (3), : 30-37. (In Indonesia)

Gunarto \& Widodo. A. F. (2012). Pengaruh perbedaan suhu air pada perkembangan larva kepiting bakau, Scylla olivacea. Prosiding Indoaqua, Forum Inovasi Teknologi Akuakultur 2012. Puslitbang Perikanan Budidaya, Jakarta, Hal : 281-287. (In Indonesia)

Gunarto \& Herlinah, J. (2013). Pemeliharaan larva kepiting bakau, Scylla olivacea menggunakan sistem air hijau. Prosiding Forum Inovasi Teknologi Akuakultur 2013. Perakitan Strain dan Pemanfaatan Induk Unggul Kesehatan Ikan dan Lingkungan. Pusat Penelitian dan Pengembangan Perikanan Budidaya, Jakarta. Hal : 1207-1213. (In Indonesia)

Gunarto \& Herlinah, J. (2015). Tingkat produksi crablet kepiting bakau Scylla paramamosain dengan pemberian pakan diperkaya dengan HUFA dan vitamin $C$ pada fase larva. Jurnal Ilmu dan Teknologi Kelautan Tropis, 7(2): 511-

\section{0. (In Indonesia)}

Gunarto, B. R. Tampangalo, Herlinah \& Syafaat, M. N. (2016). Pemeliharaan larva kepiting bakau, Scylla serrata dengan pemberian pakan alami berbeda jenis pengayanya. Makalah dipresentasikan pada seminar Forum Inovasi Teknologi Akuakultur,di Hotel Haris, Surabaya 9 April 2016. 18 p. (In Indonesia)

Hamasaki, K., Suprayudi, M.A. \& Takeuchi, T. (2002a). Mass mortality during metamorphosis to megalops in the seed production of mud crab Scylla serrata (Crustacea, Decapoda, Portunidae). Fish Sci 68 : 1226-1232.

Hamasaki, K., Suprayudi, M.A. \& Takeuchi. T. (2002b). Effects of dietary N-3HUFA on larval morphogenesis and metamorphosis to the megalops in the seed production of the mud crab, Scylla serrata (Brachiura: Portunidae). Suisanzoshoku, 50 (3): 333-340.

Hamasaki, K. (2003). Effects of temperature on the egg incubation period, and survival and developmental period of larvae of the mud crab, Scylla serrata (Forskal) (Brachiura: Portunidae) reared in the laboratory. Aquaculture, $219: 561-572$.

Herlinah \& Septiningsih, E. (2015). Reproduction performance of mud crab (Scylla olivacea) broodstocks with different feeds. International Journal of Agriculture System 3(2) : 157-168.

Jean, H. B. \& Hur. S. B. (2011). Selection of suitable spesies of Chlorella, Nannochloris and Nannochloropsis in high and low temperature seasons for mass culture of the rotifer Brachionus plica- 
tilis. Fish Aquat. Sci. 14 (4) : 323-332.

Karim, M. Y. (2006). Respon fisiologis larva kepiting bakau (Scylla serrata) yang diberi nauplius Artemia hasil bioenkapsulasi dengan asam lemak-3 Hufa. Jurnal Protein, 13 (1), : 74 - 80. (In Indonesia)

Keenan, C.P., Davie, P.J. F. \& Mann. D. L. (998). A revision of the Genus Scylla de Haan, 1833 (Crustacea: Decapoda: Brachyura: Portunidae). Raffles Bull. Zool. 46, 217 -245.

Mary, L. S-A., Fe, P-E. \& Gonzales. G. A. (2007). Acute toxicity of nitrite to mud crab Scylla serrata (Forsskal) larvae. Aquaculture Research, 38 (14), : 14951499.

Matthew, R. P., Cynthia, K. F. \& Holt. G. J. (2006). Highly unsaturated fatty acid composition of rotifers (Brachionus plicatilis) and Artemia fed varoius enrichments. Journal of the World Aquaculture Society, 37 (1), : 126-131.

Nell, L. L., ravi, F. \& Colin. C. S. (2005). Effects of acute and chronic toxicity of unionized ammonia on mud crab, Scylla serrata (Forskal, 1755) larvae. Aquaculture Research, 36 : 927-935.

Okauchi, M. (2004). An assesment of the beneficial roles of Nannochloropsis oculata in larval rearing of marine finfish. Bull. Fish Res. Agen (1) : 83-90.

Quinitio, E. T., Parado-Estepa, F. D., Millamena, O. M., Rodriguez, E., \& Borlongan. E. (2001). Seed production of mud crab Scylla serrata jeveniles. Asian Fisheries Science 14 : 161-174.

Ribeiro, E. A. L. T \& Jones, D. A. (2000). Growth and ontogenetic change in ac- tivities of digestive enzymes in Fenneropenaeus indicus postlarvae. Aquaculture nutrition, $6: 53-64$.

Shigeki, D. and Hamazaki. K. (2012). Effect of salinity and dietary n-3 higly unsaturated fatty acids on the survival, development, and morphogenesis of the larvae of laboratory reared mud crab Scylla serrata (decapoda, Portunidae). Aquaculture International, 19 (2), : 323-338.

Suprayudi, M. A., Takeuchi, T., Hamasaki, K. \& Hirokawa. J. (2002). Effect of Artemia feeding schedule and density on the survival and development of larval mud crab Scylla serrata. Fisheries Science, 68 (6), : 1295 - 1303.

Suprayudi, M. A., Takeuchi, T. \& Hamasaki. K. (2012). Phospholipids effect on survival and molting synchronicity of larvae mud crab, Scylla serrata. Hayati Journal of Biosciences, 19 (4), : 163 168.

Sui, L., W. Mathieu, Cheng Y. \& Sorgeloos P. (2007). The effect of dietary n-3 HUFA levels and DHA/EPA ratios on growth, survival and osmotic stress tolerance of Chinese mitten crab $\mathrm{Er}$ iocheir sinensis larvae. Aquaculture, 273: 139-150.

Thirunavukkarasu, N., Nesakumari, S. A. \& Shanmugam, A. (2014). Larva rearing and seed production of mud crab Scylla transquebarica (Fabricius, 1798). International Journal of Fisheries and Aquatic Studies, 2 (2), : 19-25.

Truong, T., Mathieu, N., Stijn, W., Quach, V. T. \& Sorgeloos. P. (2007a). Influence of highly unsaturated fatty acids in live 
food on larviculture of mud crab, Scylla paramamosain (Estampador, 1949). Aquaculture Research, (38), :15121528.

Truong, T. N., Mathieu, W., Tran, C. B., Hoang, P. T., Nguyen, V. D. \& Sorgeloos, P. (2007b). Improved techniques for rearing mud crab Scylla paramamosain (estampador 1949) larvae. Aquaculture Research, 38, 1539-1553.

Yousefian, M., and Najafpour. S. H. (2011). Enrichment of Artemia using Highly Unsaturated fatty Acid and Vitamin C in larvae culture of Acipencer persicus. World Applied Sciences Journal, 12 (8): 1266-1268.

Yunus, Setiadi, I., Kaspriyo \& Des Roza, 1997. Pengaruh $\mathrm{pH}$ air terhadap sintasan larva kepiting bakau Scylla serrata. Jurnal Penelitian Perikanan Indonesia III (4) : $57-61$.

Zhenguo, Q., Jiangang, W., Zhongli, Y., Keji, J. \& Lingbo. M. (2010). The novel hatchery facilities based on main effect factors of seedling rearing of mud crab (Scylla spp) in China. Journal of Life Sciences, 4 (3), : 36-42. 